International Journal of Social Science And Human Research

ISSN(print): 2644-0679, ISSN(online): 2644-0695

Volume 05 Issue 01 January 2022

DOI: $10.47191 / \mathrm{ijsshr} / \mathrm{v} 5-\mathrm{i} 1-29$, Impact factor-5.586

Page No: 202-215

\title{
Reconfiguring the Academic Success Matrix through Student Involvement: Implications for a Higher Education Institutions: A Case of Three Selected Universities in Zimbabwe
}

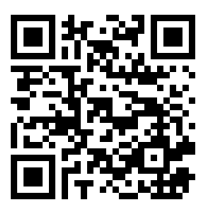

\author{
Mthuthukisi Ncube ${ }^{1,}$ Mesabe (Bhebhe) Ncube ${ }^{2}$, Sithandweyinkosi Nkomo (MSc-DS, IDS- \\ NUST), ${ }^{3}$ Daniel Tafadzwa Chikonye ${ }^{4}$ \\ ${ }^{1}$ Lecturer and Researcher- Gwanda State University, Filabusi, Zimbabwe \\ ${ }^{1} \mathrm{PhD}$ Candidate: IDS-National University of Science and Technology, Bulawayo, Zimbabwe \\ ${ }^{2}$ Alumni-National University of Science and Technology \\ ${ }^{3} \mathrm{PhD}$ Candidate (IDS-National University of Science and Technology, Bulawayo, Zimbabwe \\ ${ }^{4}$ Candidate for BEng. in Metallurgical Engineering, Gwanda State University, Zimbabwe \\ Orcid id : 0000-0002-7178-5955 $0000-0001-6683-7688^{2}$
}

\begin{abstract}
The article explores reconfiguring the concept of academic success in Zimbabwe, now premised on the attainment of benchmark Doctrine Education 5.0 pillars set by the Ministry of Higher and Tertiary Education, Innovation, Science and Technology Development and enforced by Zimbabwe Council for Higher Education (ZimCHE) as a quality assurance agency. It reviews academic success standards based on teaching and learning; research, community engagement; innovation; and industrialisation. Targeting, HEI quality assurance officers, managers, and students as the population, the study purposively selected three HEIs based on stated science, technology, engineering, and mathematics (STEM) mandates drawn from Zimbabwe's 20 registered public and private universities. Questionnaire-elicited data were analysed using the Statistical Package for Social Scientists and presented in graphs derived from descriptive statistics to enhance meaning in findings. Findings show the five-fold Doctrine Education 5.0 remains news to HEI students although they passively participate as recipients, reflected in students-asconsumers rather than 'students-as-partners' among HEIs and later industry. Without students' voice as HEI partners, success would be analogous to a maternity centre rating its success based on 'state of the art equipment' and high calibre staff without mention of babies delivered as core business therein. The article recommends the reconfiguration of the academic-success matrix to reflect the student-interests involvement, and the industrial perspective as end-line users of HEI graduates. A one-size fits-all approach to academic success is not tenable for HEIs, and their divergent mandates call for differentiated methodological approaches to achieve success. HEIs continue to rate their success in terms of student enrolment figure, infrastructural development at the expense of student-centred success criteria that assesses innovative skills capacity and industrial appraisals post-graduation. The shift to a business approach in higher education has been unmanaged, with telling implications for HEIs visions and stated missions, necessitating change. Consolidating HEI success requires Chief Executive Officers' whose proven mandate espouses all education 5.0 deliverables, particularly innovation and industrialisation through research and community engagement, except for teaching and learning. Nothing in academia prepares Professors as Vice Chancellors for this task, reducing them to duds as their grasp of the five-fold mandate largely remains superficial. HEIs' success criteria and students' involvement continue to reflect education 3.0 scope when they should functionally be operating at 5.0, which is just on paper and tick-a-box-kind-of compliance to satisfy minimum quality assurance expectations. A danger of leaving important stakeholders behind until too late lingers, with potentially telling negative ramifications therefrom for all.
\end{abstract}

KEYWORDS: Academic-success; student-involvement; student-as-partners; quality-assurance; HEI

\section{INTRODUCTION}

Perhaps because of its amorphous nature, the term 'academic success' (AS) is one of the most widely used constructs in educational research/assessment within higher education. Academic success is generally associated with the attainment of summative assessments, marked by learning outcomes (Cachia, Lynam, and Stock, 2018). However, York, Gibson, and Rankin (2015) cited in Cachia et al. (2018) argue the meaning of academic success is debatable, depending on varying subjective perspectives that shift according to the subject. Universally, people know institutions and organisations by their products rather than their industrial processes/apparatus. Higher education institutions (IHEs), adrift from the norm have had little consideration for their products, the 


\section{Reconfiguring the Academic Success Matrix through Student Involvement: Implications for a Higher Education Institutions: A Case of Three Selected Universities in Zimbabwe}

students in determining HEI academic success matrix. Consequently, student-exclusion affects academic success criteria adopted as HEI tend to craft and adopt institution and teacher-centred academic success criteria.

Student exclusion raises questions on the validity of 'academic success' achieved without students' perspective as the co-producers and consumers of HEI programmes. Student-centred academic success factors would be a cog in determining self-evaluations by IHEs towards quality assurance. Broadly, the emphasis on student success is driven by several factors, as underscored by Kinzie and Kuh (2016) including concerns about persistent inequities in educational attainment, expanding economic and workforce needs, and overall concerns about educational quality. York et al. $(2015,5)$ identify six elements defining academic success as including 'academic achievement, engagement in educationally purposeful activities, satisfaction, acquisition of desired knowledge, skills and competencies, persistence, attainment of educational outcomes, and post-college performance'. Students perceive assessments as beneficial to their learning if they are explicitly aware of how they build on their current skill set and their relevance to their future career (Lynam \& Cachia 2017; Cachia et al. 2018). In Zimbabwe, academic success derives from attaining the Ministry of Higher and Tertiary Education, Science and Technology Development benchmarks standards enforced by IHE quality assurance agency, Zimbabwe Council for Higher Education (ZimCHE). The Doctrine Education 5.0 as IHE Success Criteria entails teaching and learning; research, community engagement; innovation; and industrialisation.

\section{STUDENT AS PARTNERS}

Students as Partners ( $\mathrm{SaP})$ is a pedagogical approach that has been embraced recently by many institutions of higher education primarily in the US, the UK, Canada, and Australia and implies students and faculty/academic staff working in collaboration, as partners, to improve teaching and learning experiences (Mercer-Mapstone et al., 2017). In corroboration, Healey et al. (2014:12) describe $\mathrm{SaP}$ as "a relationship in which all involved students, academics, professional services staff, senior managers, and students' unions are actively engaged in and stand to gain from the process of learning and working together". Scholars such as Bryson, (2014a); Bryson (2014b); Curran (2017); Levy, Little and Whelan (2011); Matthews (2016); and McCulloch (2009) feel the time has come to challenge and move away from hierarchical university structures that encourage a competitive 'them and us' attitude, to more collaborative approaches. That way, staff and students work together for the mutual benefit of both, in pursuit of deep learning.

\section{STUDENT SUCCESS}

The term, "student success," is now part of the higher education lexicon. But it is defined variously, depending on who uses the term for what purposes with what audiences (Kinzie and Kuh 2016). For example, student success sometimes refers to making educational programs and services accessible to certain groups of students and the phrase is frequently used to connote what institutions can do to assist students in attaining their postsecondary aspirations (Kinzie and Kuh 2016). Student success can infer individual or group achievement levels. For state and federal policymakers, student success typically means access to affordable postsecondary education, shortened "time to degree", degree completion, and post-college employment and earnings (Kinzie and Kuh, 2016). However, the institutional perspective views student success as meaning first-year student retention, student persistence to completion, content knowledge gains, engagement in educational processes that foster a high-quality undergraduate experience, and even students' personal success (Kinzie and Kuh 2016).

\section{ACADEMIC SUCCESS}

Jeffrey (2011) posits among many indicators of academic success are factors that included but were not limited to GPA, graduation rate, retention rate, annual salary the first year after graduation, and placement percentage of graduates. Studies identified academic success factors as two pronged: student factors as well as teaching factors. Personal: cognitive factors like anxiety loneliness influenced academic success (Mihaela 2015; McKenzie \& Schweitzer, 2001; Ross, Drysdale, \& Schulz, 2001; Zhang and Aasheim 2011). Course level: lecturers' behavior, teaching methods, subject matter, and student-lecturer interaction influenced academic success (Aysan, Tanrı̈ğen, \& Tanrı̈ğen, 1996; Mayer \& Patriarca, 2007). Social factors: culture differences (Aysan et al., 1996; Zhang and Aasheim 2011). Another problem in the academic success research is the tautology where one dependent variable is used to test another dependent variable. For instance, success in one course is used to predict success in another (Brookshire, Crews, \& Brown 2009; Jeffrey, 2011).

Each HEI's peculiarity has not been given prominence, yet IHEs are not necessarily identical nor are their students. Scholars found few studies based on student perspectives of academic success (Zhang and Aasheim, 2011). Often, researchers examining academic success quantify it based on assessment grades (Cachia, Lynam and Stock, 2018). Scholars are quick to point to the flaw of using academic success that is devoid of student's perspective and thus argue academic success cannot be defined for students since different students may have different definitions of academic success (Jeffrey 2011; Cachia, Lynam and Stock 2018). The scholar notes that a student might define success differently than a faculty member or an administrator (Jeffrey 2011; Cachia et al. 2018). 


\section{Reconfiguring the Academic Success Matrix through Student Involvement: Implications for a Higher Education Institutions: A Case of Three Selected Universities in Zimbabwe}

Depending on how success is defined, the factors that are important to success could vary (Cachia et al. 2018). This assumption is questioned by considering the students' conceptualisation of academic success (Cachia et al. 2018) who identify 6 elements for academic success that include 'satisfaction, acquisition of desired knowledge, skills and competencies, persistence, attainment of educational outcomes, and post-college performance' (2018:5). Busato, Prins, Elshout, and Hamaker (2000) assert students' learning style and achievement motivation affect academic success. The government of Zimbabwe through the Council for Higher Education Act (ZIMCHE) (2006) set up ZimCHE. Many IHEs do not have formal quality promotion policies or structures to meet the audit requirements and are in the process of reviewing their practices (Majoni, 2014; Tapera and Kuipa, 2016).

Most Zimbabwean IHEs use peer review as the main quality assurance mechanism. Engaging students to define their academic success perspective is a necessary avenue for exploration, and therefore planning of how they can achieve their goals throughout their time at university and beyond Senate is the main quality assurance body. Reliance is on external reviewers or examiner. The paper pursues reconfiguring academic-success matrix by IHEs. Tracks student-involvement component therein and proposes change-management processes toward quality assurance. IHEs have, during the massification of higher education reduced success criteria to increased enrolment and graduation figures captured in Vice Chancellor's Reports, Graduation speeches marked by statistics depicting 'this success'. Oblivious of downstream utility to graduated students, employing industry and community in goods and services.

Herminio (2005) cited in Aluko, Adenuga, Kukoyi, Soyingbe and Oyedeji (2016) classified two factors affecting academic success, namely: internal and external factors. The internal factors are class schedule, class size, classroom environment, role of the lecturers, technology and nature of examination while the external factors include extracurricular activities, family and work activities. Herminio's (2005) findings show that internal factors are much more significant than the external factors. Further, Ling et al. (2010) cited in Aluko et al. (2016) examined the effect of teaching and learning approaches on academic performance. It was found that the growing teaching approach and the achieving motive learning approach are related to improved academic success. Similarly, studies (e.g. McKenzie and Schweitzer 2001; Win and Miller, 2005) cited in Aluko et al. (2016) have demonstrated that prior academic performance has significant impact on the academic success of first-year university students. Scholars contend numerical assessment scores/grades obtained in a subject may not be a true reflection of the knowledge gained by a student on a topic/subject; a numerical score/grade obviously remains the most available proxy for measuring academic success (Bone and Reid 2011; cited in Aluko et al. 2016).

Wilson et al. (2014); cited in Haughery (2017) postulate student engagement as an intermediate outcome to academic success that is evident in students within a shorter timeframe than other facets such as academic achievement and persistence. Citing Nelson et al. (2015), Haughery (2017) considers student engagement as directly proportional to learning achievement by students wherein Von Strumm, Hell, and Chamorro-Premuzic (2011); cited in Haughery (2017) found the interaction effects between student effort and student intellectual engagement such as intellectual curiosity to be a good predictor of academic success. Similarly, Light (1992, 2004) cited in Haughery (2017) denote student engagement, marked by student involvement in learning, as a critical factor in educational development, while Kamphorst, Hofman, Jansen, and Terlouw (2015) argued it was pivotal to student persistence. Pintrich, Smith, García, and McKeachie (1993) suggest engagement to be a function of student motivation cited in cited in Haughery (2017).

Engagement requires not only being active but also feeling and sense making (Harper and Quaye 2009; cited in Gunuc 2014). Bomia and colleagues (1997) define student engagement as students' willingness, needs, desire motivation and success in the learning process. Hu and Kuh (2001) and Kuh (2009) refer to student engagement as the time allocated by students to educational activities to contribute to the desired outcomes and as the quality of their related efforts. Stovall (2003) cited in Gunuc (2014) suggests student engagement includes not only the time students spend on tasks but also their willingness to take part in activities wherein Krause and Coates (2008) associate student engagement with high quality in learning outcomes (cited in Gunuc 2014).

\section{STATEMENT OF THE PROBLEM}

There is need to ensure academic success affects stakeholders positively (not necessarily the same way). Student involvement has been peripheral among IHEs, straddling on manipulation and tokenism at most. HEI management has been mired in inefficiency lamented as lack of relevance of HEI management qualifications, skills and experience to higher education mandates. Students are preferentially involved. Enrolled to existing programme designs; measured based on existing success criteria and rules. Previous studies show that employers feel HEI graduates are too theoretical, have wrong attitudes, and were unwilling to learn. Students face the problem of unemployment since employers feel universities are offering courses that are not in line with their requirements and graduates are ill-equipped for the jobs available (Nherera 2000). The challenge is to produce graduates whose knowledge and skills create employment; produce goods and services; and are employable by relevant industry, yet without involving industry in crafting the IHE mandates, itself reflecting lack of multi-stakeholder management approach. York et al. (2015) suggest the importance and imperative of academic success through achieving set objectives of knowledge and skill development during the process of learning 


\section{Reconfiguring the Academic Success Matrix through Student Involvement: Implications for a Higher Education Institutions: A Case of Three Selected Universities in Zimbabwe}

with goods and services. They underscore the need to reconfigure the academic success matrix through student involvement by highlighting implications for higher education institutions in Zimbabwe understand factors underlying students' academic success among IHEs (York et al., 2015).

\section{RESEARCH QUESTIONS}

What academic success criteria do IHEs students want? What were the students' roles in crafting the Doctrine Education 5.0? How are student involved vis-à-vis IHE success criteria? Of what relevance are IHE management skills set to IHE stated mandates?

Fig.1: Theoretical Framework- Partnership Model for Academic Success

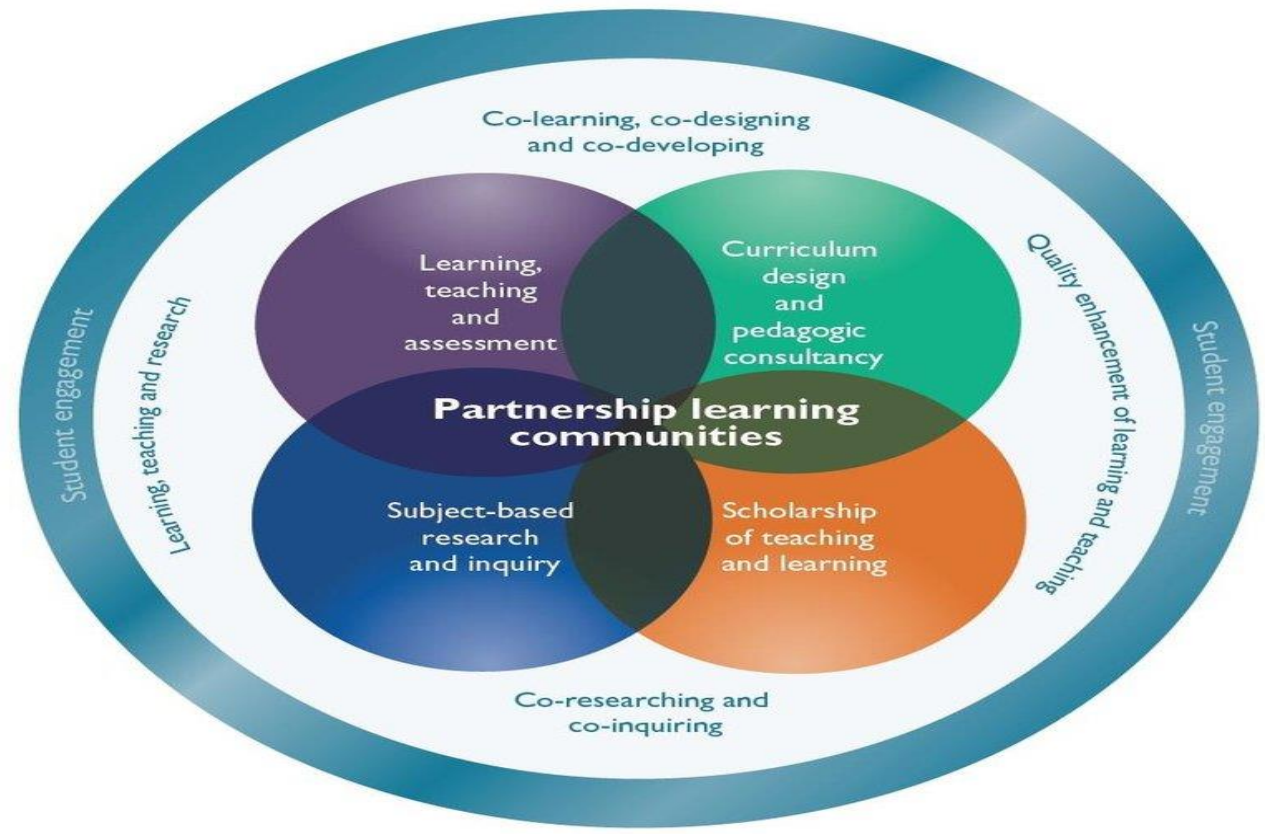

The figure 1 above portrays engaging students as partners as a powerful idea, the implementation of which has the potential to transform higher education (Healey, Flint and Harrington, 2014). Cook-Sather, Bovill and Felten, 2014) for example, highlight that benefits for students and faculty engaging in learning and teaching partnerships are similar and include increased engagement with learning and enhancement activities, transformed thinking about teaching and learning, and developed awareness of one's own role and agency in the wider academic learning community. More succinctly put, Hardy and Bryson (2016); Curran (2017); MercerMapstone, Dvorakova, Matthews, Abbot, Cheng, Felten, Knorr, Marquis, Shammas and Swaim (2017) describe such partnership as student-staff partnership (SSP). This partnership is gaining momentum in teaching and learning in higher education as an enabler of student engagement to co-design e-learning materials and support learner engagement Mercer-Mapstone et al., 2017).

Partnerships and collaborations are advocated as a means to address problems plaguing higher education (Eddy, 2010). Institutions of higher education often partner because they share interest in students' success through focus on student learning initiatives (Eddy, 2010). When defining partnership, Cook-Sather et al. (2014) underscore respect, reciprocity and responsibility as three important principles to be taken into account in all partnerships in higher education. These basic characteristics of successful partnership set faculty and students up for developing trusting and respectful relationships, for sharing not only power, but also risks and responsibilities for learning (Cook-Sather et al., 2014). Scholars have argued that "leadership should consider partnership and reciprocity, upon which partnership is based as fundamental for success" (Cook-Sather and Felten, 2017:175). These principles are reinforced by five determinants to partnership success that include commitment to partnerships, curriculum and learning, quality and risk management, geographic and economic settings, and change management (Chou, 2012).

The imperative of student involvement is highlighted in arguments by The National Union of Student's (NUS (2012:8) who argue that "at its roots partnership is about investing students with the power to co-create, not just knowledge or learning, but the higher education institution itself. Students as partners as a concept interweaves through many debates, including assessment and feedback, employability, flexible pedagogies, internationalisation, linking teaching and research, and retention and success (Healey et al., 2014). The scholars outline eight principles and values underpinning student partnership success explained as follows:

Authenticity: all parties have a meaningful rationale for investing in partnership, and are honest about what they can contribute and the parameters of partnership. Inclusivity: partnership embraces the different talents, perspectives and experiences that all parties 


\section{Reconfiguring the Academic Success Matrix through Student Involvement: Implications for a Higher Education Institutions: A Case of Three Selected Universities in Zimbabwe}

bring, and there are no barriers (structural or cultural) that prevent potential partners getting involved. Reciprocity: all parties have an interest in, and stand to benefit from, working and/or learning in partnership. Empowerment: power is distributed appropriately and all parties are encouraged to constructively challenge ways of working and learning that may reinforce existing inequalities. Lastly, Trust: all parties take time to get to know each other, engage in open and honest dialogue and are confident they will be treated with respect and fairness. Challenge: all parties are encouraged to constructively critique and challenge practices, structures and approaches that undermine partnership, and are enabled to take risks to develop new ways of working and learning. Community: all parties feel a sense of belonging and are valued fully for the unique contribution they make. Responsibility: all parties share collective responsibility for the aims of the partnership, and individual responsibility for the contribution they make (HEA, 2014; Healey et al., 2014:14-15).

Engaging students actively in their learning is the most common form of partnership. Only where students are given a significant amount of autonomy, independence, and choice can this be considered partnership. "High impact" learning experiences in terms of retention and depth of learning (Kuh, 2009) and generating student engagement (Evans, Muijs, \& Tomlinson, 2015) are characterised by active and experiential learning (Healey et al., 2016). SaP places responsibility of teaching and learning on teachers and students, arguing that students have an active role to play in the decisions about what and how to learn. The Students as Partners model challenges and scrutinizes foundational features of current higher education system. These include but not limited to among others: Its non-democratic, hierarchical structures; its focus on predetermined learning outcome; and its view of student as client. Bovill and Bulley (2011, p.181) also give specific examples of what each ladder of ASP might look like in practice. For example, 'Partnership - a negotiated curriculum' could be "student experience and work used as basis for curriculum; students actively and meaningfully negotiating curriculum with tutor" (2011, p.181); 'Students in control' might involve "Student designed learning outcomes and projects. Student led journal clubs, student led journals" (2011, p.181). They also acknowledge that "locating examples of this top rung is challenging within the current higher education context, where our systems of quality assurance require courses to be validated and reviewed on the basis of clear intended learning outcomes and assessments".

\section{RESEARCH METHODOLOGY}

This study used a mixed methods research design. A "mixed method design" is characteristic of post-positivist research wherein researchers within this paradigmatic purview outline several shortcomings of using quantitative research techniques in isolation when seeking to understand complex social issues (Phoenix, Osborne, Redshaw, Moran, Stahl-Timmins, Depledge, Fleming \& Wheeler, 2013), hence the incorporation of qualitative measures to address such shortcomings. Mixing methods can, therefore, be viewed as a pragmatic style to conducting research (Creswell and Plano Clark, 2011; Phoenix et al., 2013), and has risen in popularity over the last 20 years (Johnson et al., 2007; Phoenix et al., 2013). In this context, gathering data using both quantitative and qualitative methods produces a range of results, which are subsequently triangulated to provide an overarching finding (Phoenix et al., 2013).

The approach under this purview is thus mixed in nature, combining inductive and deductive reasoning to research that fuse objective and subjective reality to enhance fuller understanding of phenomena. The metaphor of a triangle signals the use of multiple reference points to locate a singular position (Denzin, 1978; Phoenix et al., 2013). Crucially, it is this act of seeking an objective, singular truth through the processes of triangulation, which differentiates the post-positivist from the interpretive paradigm (Phoenix et al., 2013).

The study used the multi-case study research strategy that assessed for reconfiguration a selected institution of higher education in Zimbabwe. The IHEs were conveniently selected for accessibility to the researchers and used to identify students' preferred success criteria among IHEs; describe student involvement challenges in crafting IHE success criteria towards reconfiguring the academic success criteria IHEs use from a student involvement perspective. The three IHEs were conveniently selected from a sampling frame comprising 24 registered universities including 14 State-run universities (Ncube, 2019; Garwe and Thondhlana, 2015).

Multistage sampling was used which included purposive targeting of offices known to handle quality assurance issues from them referrals were followed as snowballing to fifteen respondents. The study targeted a population of quality assurance managers and officers among the three IHEs and members of the Student Representative Council (also known variously as Student Executive Council). Fifteen (15) respondents completed questionnaires whose data were entered in and run using the Statistical Package for Social Scientist (SPSS). Results are presented and discussed below. 
Reconfiguring the Academic Success Matrix through Student Involvement: Implications for a Higher Education Institutions: A Case of Three Selected Universities in Zimbabwe

\section{RESULTS AND DISCUSSION}

Fig.2: Doctrine 5.0 Success Criteria's Relevance to IHE Students

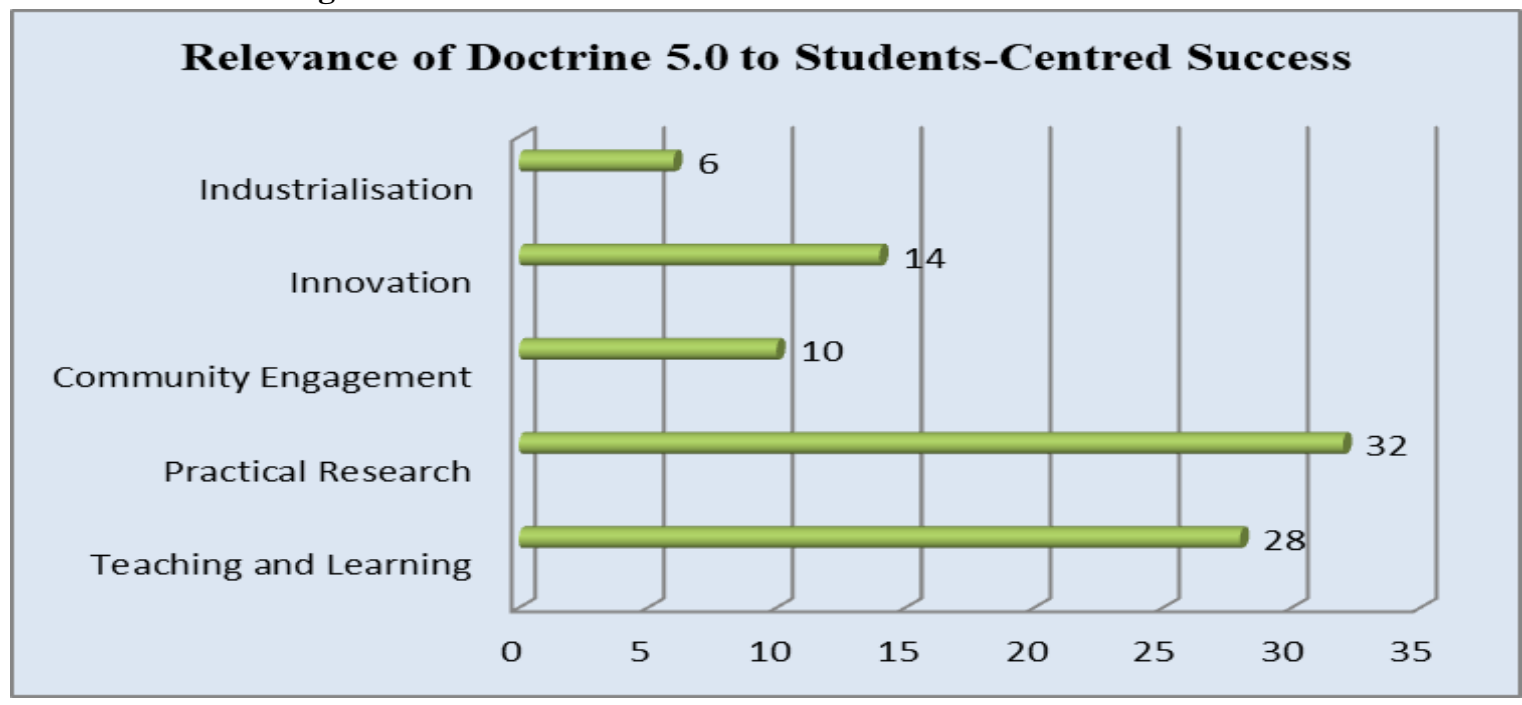

Fig.2: Success Criteria Factors

The figure 2 above highlights the relevance of the Doctrine Education 5.0 to students. Asked to select the top two most relevant components of the doctrine for student centred success, respondents' views are depicted in Fig. 2 above. Respondents require practical research to lead while teaching and learning among STEM IHEs supports what students have seen and used in practice. Community engagement; innovation, and industrialisation were a distant third, fourth and fifth respectively.

Fig. 3: Student's Roles in Crafting Academic Criteria: Ranking out of 5 each of the Following Student as Partner Components

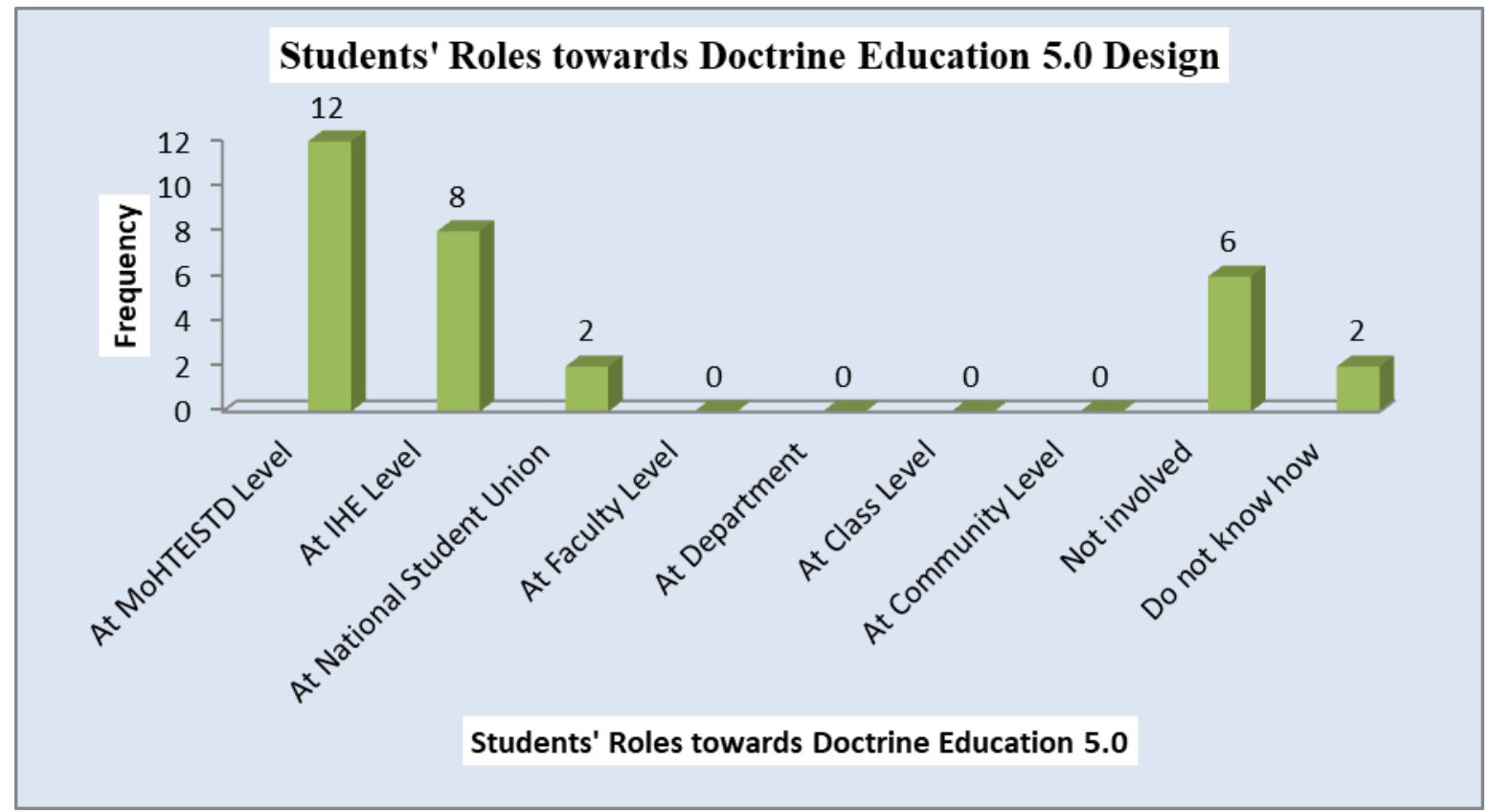

Clearly, Figure 3 above shows the extent of student involvement towards the attainment of the country vision enshrined in the Doctrine Education 5.0 of producing IHEs whose output involves goods and services as well as graduates of utility to both industry and communities through the same. The figure highlights this drive as fronted mainly by the Ministry of Higher Education, Innovation, Science and Technology Development and closely reflected among IHE management level (8) although such student involvement is barely visible at other for all other levels, hence marked by contrasting non-involvement (6) and ignorance (2) about the doctrine among IHE stakeholders. Non-involvement of students as business stakeholders is indicative of inadequately skilled IHE chief executive officers; hence Chou (2012) alludes to "outsourcing should be seriously considered as an institutional strategy for any product, service, facility, or function that campus engages in, so long as it helps fulfil the institution's mission". With IHE 
Reconfiguring the Academic Success Matrix through Student Involvement: Implications for a Higher Education Institutions: A Case of Three Selected Universities in Zimbabwe

management technically skilled in specific niches taught by IHEs rather than managerial conceptual skills, yet being at the helm of IHEs, outsourcing is not implementable.

Fig. 4: Students' Ranking of Doctrine 5.0 for Academic Success

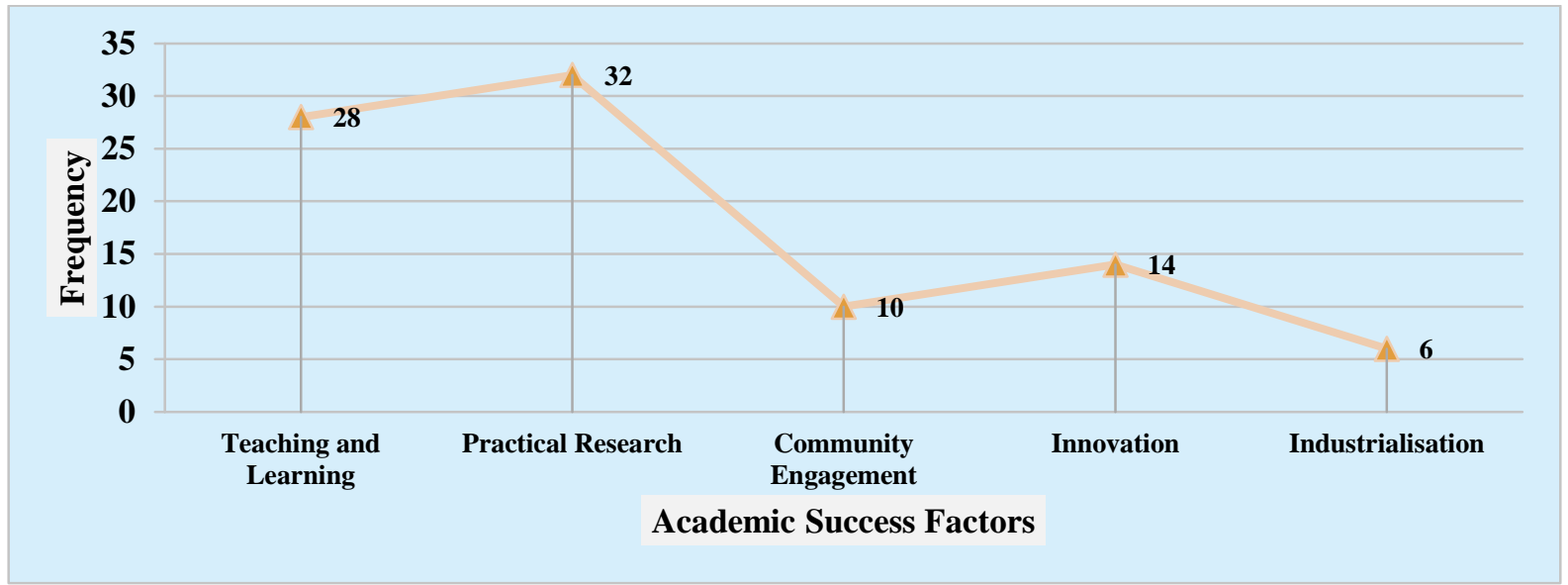

Of the five key result areas against which IHEs are evaluated by the quality assurance agency (i.e. ZimCHE), the evidently understood and prominent success factors recognised by IHEs are teaching and learning as well as practical research. The two make up the bulk of IHE activities (lecture rooms and during dissertation), as routines outside which little student involvement takes a dip in community engagement, innovation and industrialisation depicted in figure 4 above. Scholars variously argue such a grotesquely skewed bias tends towards the argument by Bryson, 2014a; Bryson, 2014b; Levy et al. 2011; Matthews, 2016; McCulloch, 2009, Curran, 2017) that its time to challenge this paradigm and move away from hierarchical university structures entrench 'them and us' attitudes, to more collaborative approaches. In these, staff and students work together for the mutual benefit of both, in pursuit of deep learning such as community engagement; research-innovation; and industrialisation wherein students are in control of their learning process. Clearly, IHEs' success criteria exclude student interests and involvement, tending toward top-down teaching and research where students are handheld and exercise no control of their own.

Fig. 5: Students' Involvement in Academic Success Criteria of IHE

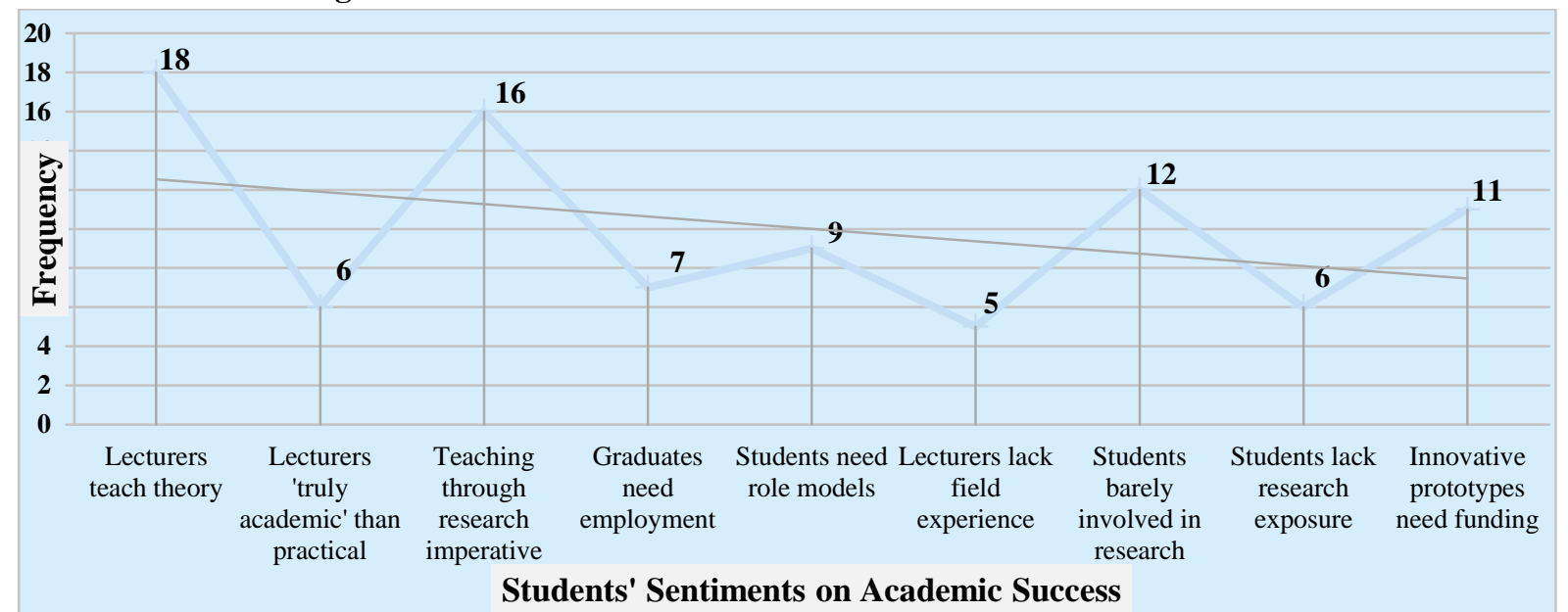

Figure 5 depicts the academic success factors among IHEs and the frequency of their reference by respondents of IHEs as such dominated by top down approaches that subdue students' voice in the core business of IHEs. Dominant emergent themes include that: 'lecturers teach theory' (18) in which is subsumed 'lecturers truly academic than practical' (6); hence justify 'teaching through research imperative' (16) which also implies 'students barely involved in research' (12); to 'innovative prototypes need funding' (11) respectively. Scholars have posited the desirability to move from a content-focused, teacher-led climate to learning approaches that focus on what the student does and engages students in active learning (Biggs and Tang, 2011; Entwistle, 2009; Curraan 2017). Doctrine Education 5.0 Components Analysis- Fig.6: Teaching \& Learning

The section juxtaposes the Doctrine Education 5.0 components used by ZimCHE to evaluate IHEs in Zimbabwe against the eight point standard template of 'students as partners' factors that include authenticity; reciprocity; inclusivity; empowerment; trust; community; and responsibility. 
Reconfiguring the Academic Success Matrix through Student Involvement: Implications for a Higher Education Institutions: A Case of Three Selected Universities in Zimbabwe

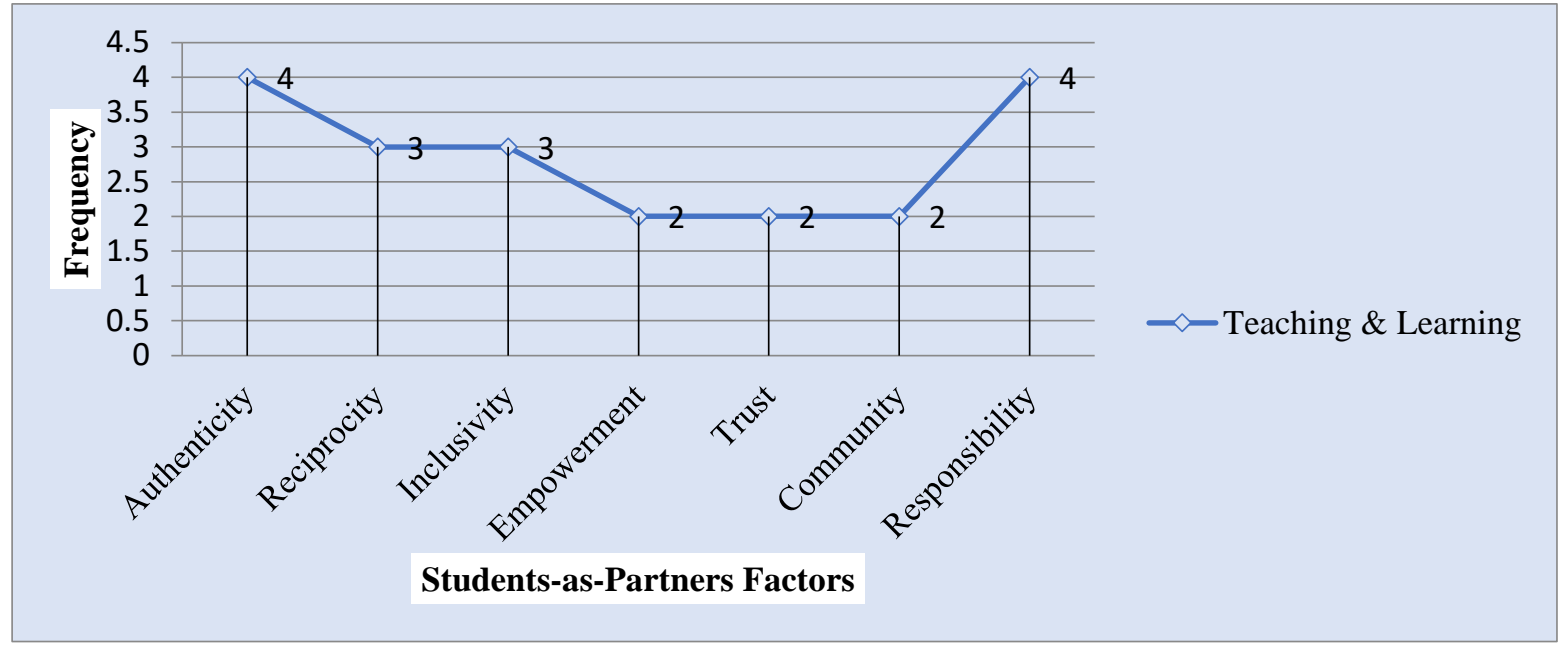

Figure 6 above shows a lack of empowerment approaches to IHE delivery; lack of trust in student involvement exacerbated by unshared responsibility for IHE activities. This explains the reliance on teaching and learning as the main method of delivery and research at the terminal part of the students' studies for dissertation.

Fig.7: Research vis-à-vis Eight Students as Partners' Components

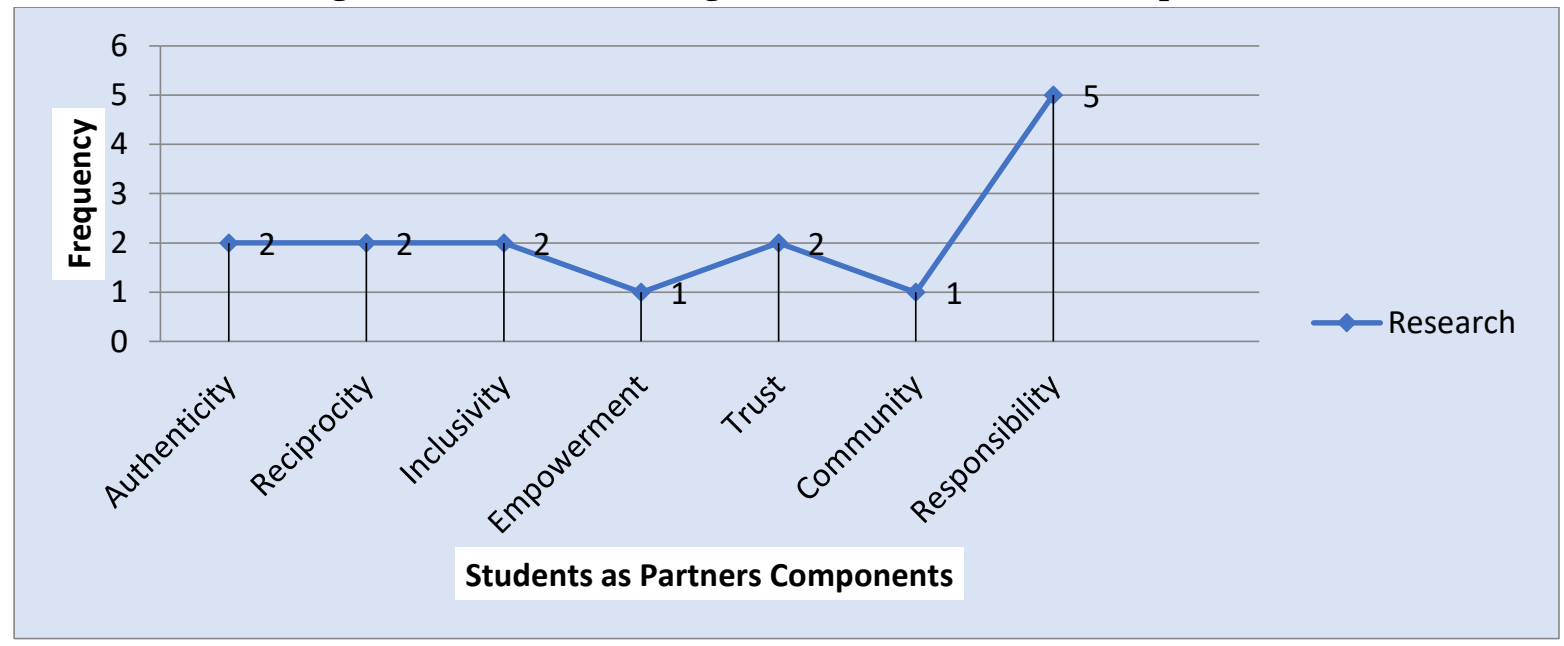

In the figure 7 above is clearly shown the consistency with which authenticity, reciprocity and inclusivity have been treated among IHEs at a minimal level while the empowerment component has been neglected, reflected by a dip where trust and community concept are equally at minimal levels. Although the study notes that responsibility has been shared by IHEs, arguably, this has been on research as partial fulfillment of the requirements of each of the programmes as dissertations done by students. Healey et al. (2014) recommend subject-based research and inquiry.

Fig. 8: Community engagement vis-à-vis the eight components of students as partners

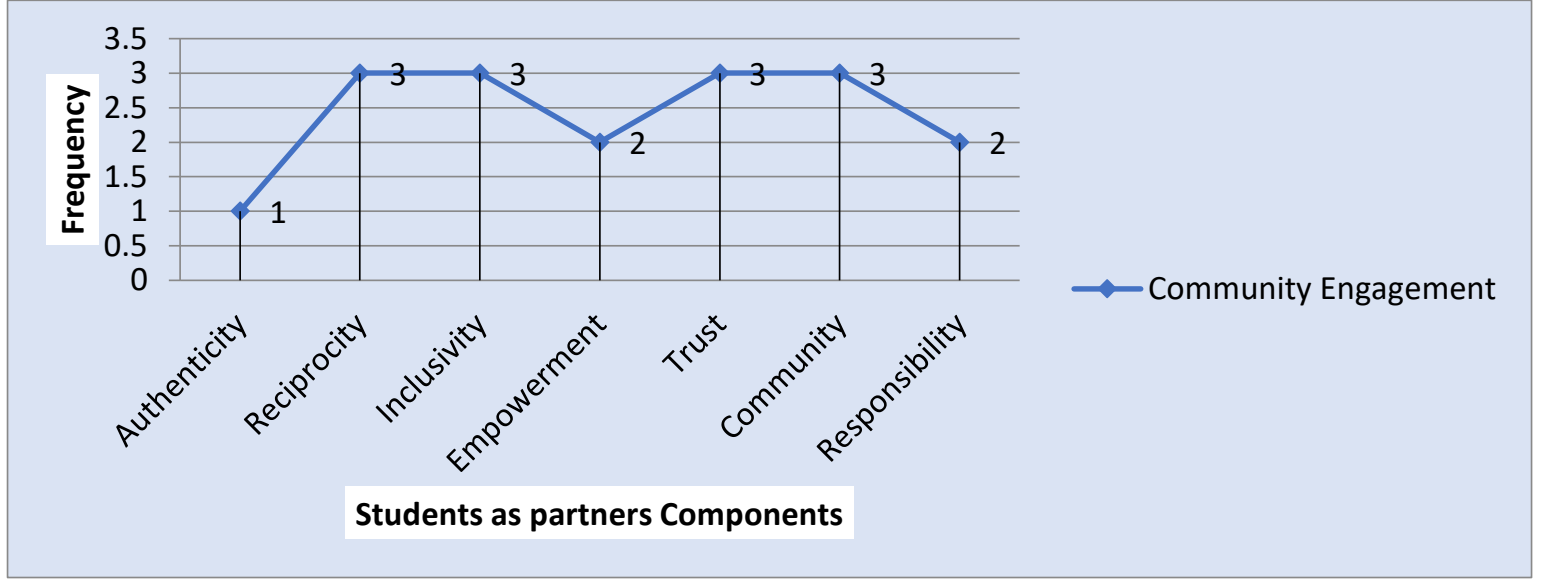


Reconfiguring the Academic Success Matrix through Student Involvement: Implications for a Higher Education Institutions: A Case of Three Selected Universities in Zimbabwe

There is lack of authenticity in the nature of community engagement undertaken by IHEs for student teaching and learning purposes although reciprocity, inclusivity has been fostered mainly through industrial attachment within communities. Empowerment attempts remain suppressed although students have been trusted more in engaging the community in a sense of belonging and responsibility therein. This may of necessity positively contribute to positive student learning outcomes per se since students engage communities on other activities like sporting.

Fig. 9: Innovation vis-à-vis Students as Partners Components

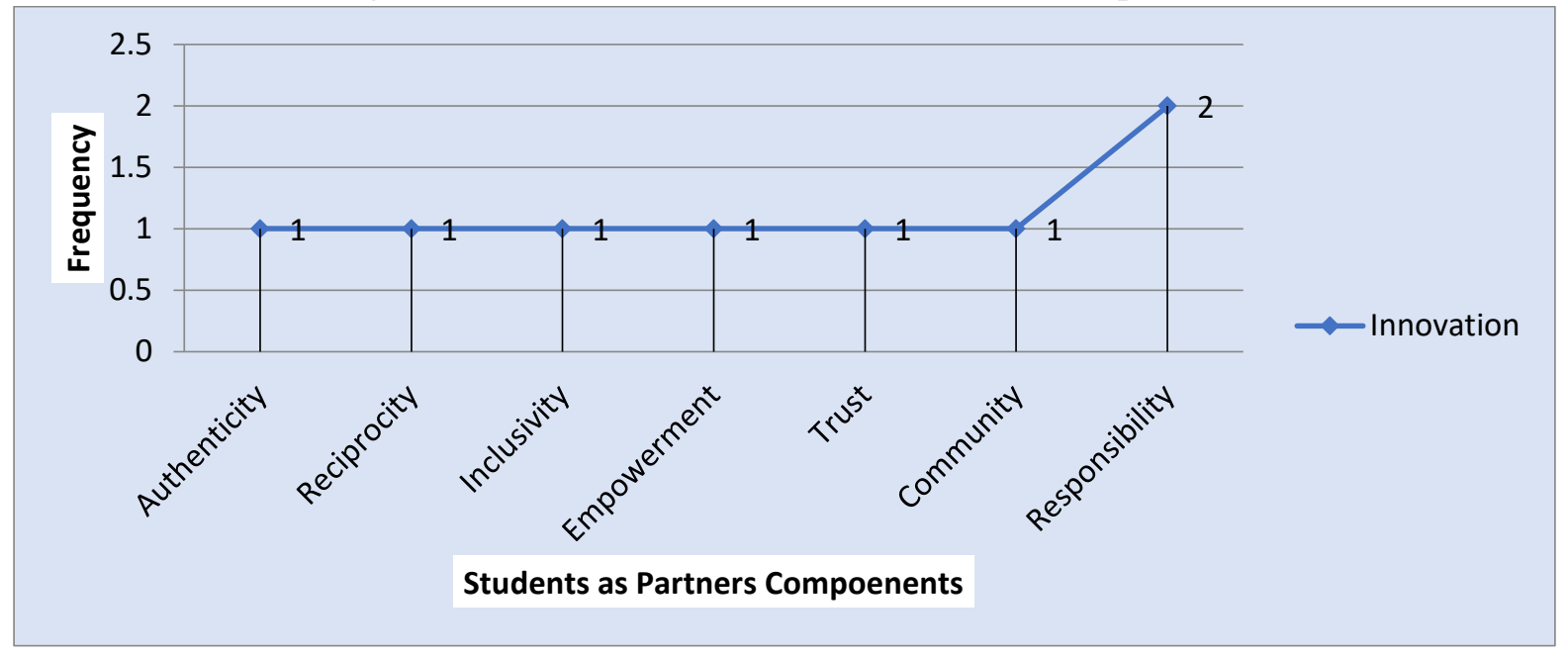

Innovation as a form of teaching and learning for both staff and students has largely been constant in its consistency of inadequacy across all components except responsibility given to students without corresponding support, financial empowerment, hence the study scored lowly in authenticity of such responsibility for innovation.

Fig. 10: Industrialisation vis-à-vis Students as Partners Components

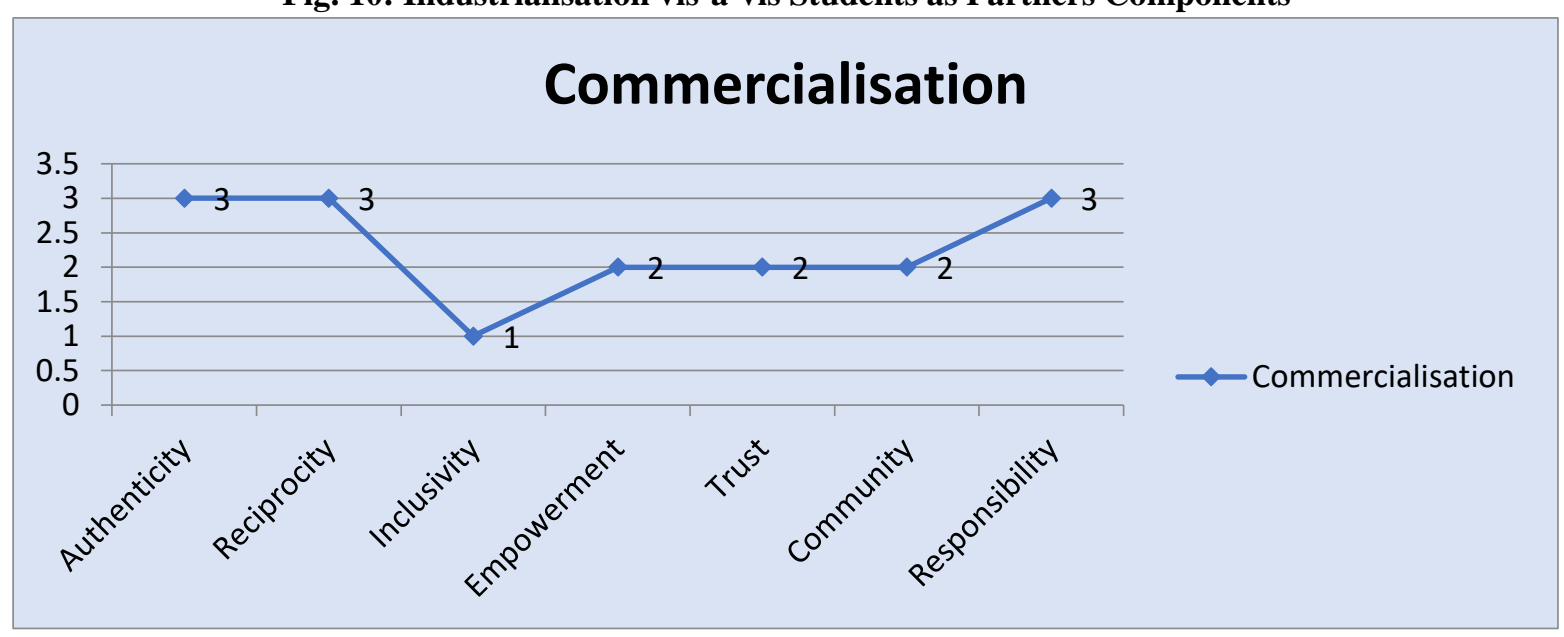

Fig.11: Relevance of IHE Management Skills Set to IHE Stated Mandates

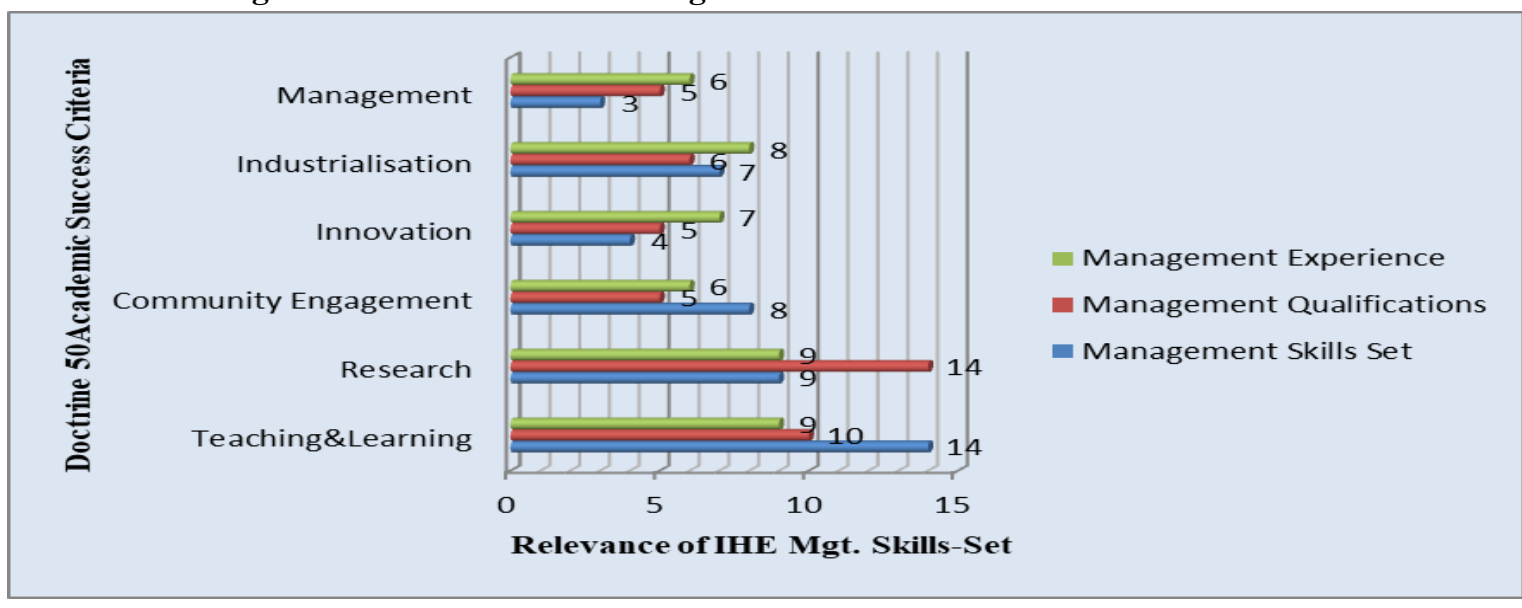




\section{Reconfiguring the Academic Success Matrix through Student Involvement: Implications for a Higher Education Institutions: A Case of Three Selected Universities in Zimbabwe}

The figure 11 shows the relevance of IHE management's qualification, skills and experiences vis-à-vis the doctrine education 5.0 deliverables for which they are responsible. The mode (the highest frequency) marked by respondents who hold the view IHE management skills-set (14) and qualifications (14) set them apart for 'research' and 'teaching and learning' as the over-arching deliverables matching their qualifications and skills. IHE management qualification and experience, from the figure above are closely related and directly linked to the achievement of teaching and learning (12); research (12); industrialisation (8); innovation (7); and lastly community engagement in that order. Of the above 5.0 academic success criteria, a negligible six felt IHE management's experience (6) positioned them for management, followed by those who felt the qualifications (5) were befitting to deliver on stated IHE mandates and lastly management skills-set (3)'s appropriateness for IHE management.

These are a far cry when juxtaposed with IHE core business as depicted by teaching and learning, research, community engagement, innovation and industrialisation respectively. From the figure 11 above, one can glean that IHE managers, who are branded Vice Chancellors and often hold Professorship titles are adequately skilled to handle two of the five academic success criteria (Teaching and Learning, as well as research through which their titled are earned). However, the innovation,

Industrialization /commercialization and community engagement, within which student involvement/engagement falls) are a domain where business chief executive officers excel and have grown large corporations through. It is thus prudent to allow such CEOs to lead IHEs while Professors deputies them for academic success standards.

\section{SUMMARY AND CONCLUSION}

This section unpacks the conclusions and recommends the appropriate action at three levels, first the policy level that targets legislative reforms on IHE management; then implementation level for University Councils and the IHE Senior Management; lastly, recommendation for further study.

\section{WHAT ACADEMIC SUCCESS CRITERIA DO IHES STUDENTS WANT?}

Students-as-partners or co-producers at institutional levels were not consulted when the Doctrine Education 5.0 was crafted, to the neglect of many would be success factors from students and industries that consume them as products post-graduation. Engaging students as partners is a powerful transformative idea supported by Healey et al. (2014) whose implementation requires change and its management in higher education.

Cook-Sather et al. (2014) for example highlight benefits for students and faculty engaging in co-designing; co-developing curriculum; co-researching; co-learning; and teaching partnerships including increased engagement with learning and enhancement activities, transformed thinking about teaching and learning, and developed awareness of one's own role and agency in the wider academic learning community. More succinctly put, Hardy and Bryson (2016); Curran (2017); Mercer-Mapstone, Dvorakova, Matthews, Abbot, Cheng, Felten, Knorr, Marquis, Shammas and Swaim (2017) describe such partnership as student-staff partnership (SSP).

Such partnership is gaining momentum in teaching and learning in higher education as an enabler of student engagement to codesign e-learning materials and support learner engagement Mercer-Mapstone et al., 2017). There is a gap in the academic success criteria, of management capabilities among IHE managers yet this is not one of the academic success criteria used in Zimbabwe despite that fact that MoHTEISTD and ZimCHE expect such management prowess to just follow.

\section{WHAT WERE THE STUDENTS' ROLES IN CRAFTING THE DOCTRINE EDUCATION 5.0?}

Students not involved in crafting the Doctrine Education 5.0 that emphasises lecturer-biased deliverables and are barely applicable to students. Students view themselves as the core of IHE mandates hence argue their views are necessary in the Doctrine. Students participate in virtually all the five criteria of success not as partners but rather than passive recipients.

The study concludes academic success is measured from an institutional perspective. All interests must be captured when crafting important criteria like the Doctrine Education 5.0, including industry, IHEs, students in IHEs, communities, research institutes, funders, private sector and government entities alike to guarantee success.

\section{HOW ARE STUDENT INVOLVED VIS-À-VIS IHE SUCCESS CRITERIA?}

At individual level, students view academic success criteria largely as peripherally relevant on three of the five criteria. These are 'practical research' conducted during the terminal part of student life at IHE through dissertation, lecture-room experiences through 'teaching and learning' and potential 'innovation' respectively and viewed community engagement and industrialisation as lesser concerns to them but the IHEs and other stakeholders. The study concludes academic success criteria are subjective and varied to different stakeholders hence a one-size-fits-all template cannot be applied successfully. 


\section{Reconfiguring the Academic Success Matrix through Student Involvement: Implications for a Higher Education}

Institutions: A Case of Three Selected Universities in Zimbabwe

The shift in IHE management and governance was remarkable change within higher education that was unmanaged, with telling implications for IHEs visions and stated missions that are divorced from expectations of other stakeholders like industry as the actual consumers of IHE products, the students.

\section{OF WHAT RELEVANCE ARE IHE MANAGEMENT SKILLS SET TO IHE STATED MANDATES?}

Bringing together the bigger IHE picture requires in a manner designed to achieve and pull together towards stated overall vision and mission is a Chief Executive Officer's mandate, for which few if any academics are trained or prepared despite being thrust into host leadership positions they find themselves in as Vice Chancellors and Pro-Vice Chancellors respectively, hence often fail in that aspect of management.

The mandates IHEs are given under the current higher education perspectives that demands the satisfaction of all IHE stakeholders, whether as clients, customers, consumers, or co-producers require a business approach to the whole sector yet those specifically described as the relevantly skilled and qualified have none of the skills set that make a business executive but one of a top academic instead.

The study concludes that professors are least qualified and skilled to lead IHEs on the implementation of IHE success criteria as they currently stand under Doctrine Education 5.0. An envisioned dichotomized reconfiguration of the success criteria as conclusions juxtaposing current expertise between professors and business executive (CEOs) by criterion is outlined below:

\begin{tabular}{|c|c|}
\hline CRITERIA & AS CURRENTLY STANDS IN PRACTICE \\
\hline 1. Teaching & $\begin{array}{l}\text { This is a specialised area of expertise presided over by top academics like } \\
\text { Professors/PhD holders in various disciplines. Lecturers ought to continuously learn } \\
\text { how to deliver better outcomes in IHEs to stay abreast with global demands and } \\
\text { success standards, hence separation for measurability of outcomes. }\end{array}$ \\
\hline 2. Learning & $\begin{array}{l}\text { This ought to be separated from teaching since they do not belong to one category and } \\
\text { are not presided over by the same group. This is a specialised area presided over by } \\
\text { IHE students and is marked by active listening, mastery, learning, and practice } \\
\text { (application) under tutelage by lecturers, instructors and technicians as appropriate. }\end{array}$ \\
\hline 3. Research & $\begin{array}{l}\text { This domain is currently shared between both IHE academics and business } \\
\text { organisations albeit with different outputs. Academics use research to resolve societal } \\
\text { problems culminating in publications that contribute to new knowledge while } \\
\text { business organisations use research to determine markets, innovate and } \\
\text { commercialise/industrialise. Thus research in IHEs must have been coupled with the } \\
\text { logical output of publications rather than innovation and industrialisation. } \\
\text { Alternatively, the doctrine education } 5.0 \text { (D.E 5.0) must have come with a paradigm } \\
\text { shift, handing IHEs to CEOs as Vice Chancellors based on expertise that favour such } \\
\text { a scenario, with } 4 / 5 \text { of the current success criteria dominantly presided over by CEOs } \\
\text { against } 1 / 5 \text { in favour of teaching presided over by professors and PhD holders who } \\
\text { are largely 'academic' in approach. } \\
\text { It is recommended research be split to two, with (a) focusing of research for } \\
\text { publication while (b) research for innovation and commercialization. }\end{array}$ \\
\hline 4. Innovation & $\begin{array}{l}\text { Special area of expertise currently presided over by business executives such as } \\
\text { Econet Wireless; United Refineries, Delta Beverages among others. This area is too } \\
\text { broad and requires subdivision to a) Theory-producing innovation; b) } \\
\text { Products/Service producing innovation }\end{array}$ \\
\hline $\begin{array}{l}\text { 5. Industrialisation / } \\
\text { Commercialisation }\end{array}$ & $\begin{array}{l}\text { This is currently presided over by business organisations albeit slow. It also ought to } \\
\text { be subdivided into two, with a) Consultancy Services and b) Products }\end{array}$ \\
\hline $\begin{array}{l}6 . \quad \text { Community } \\
\text { Engagement }\end{array}$ & $\begin{array}{l}\text { This area is shared by IHEs and business organisations through: } \\
\text { Business Organisations: } \\
\text { Market Surveys } \\
\text { Corporate Social Responsibility (CSR) } \\
\text { Source of Employees/Markets } \\
\text { IHEs Domain: } \\
\text { Problem solving research (applied research) }\end{array}$ \\
\hline
\end{tabular}


Reconfiguring the Academic Success Matrix through Student Involvement: Implications for a Higher Education Institutions: A Case of Three Selected Universities in Zimbabwe

\begin{tabular}{|l|l|}
\hline & $\begin{array}{l}\text { Attachment/Field based practical learning } \\
\text { Source of students }\end{array}$ \\
\hline & \\
\hline & \\
\hline
\end{tabular}

\section{RECOMMENDATIONS}

\section{Policy level: MoHTEISTD and ZimCHE}

Change from Education 3.0 needs to be managed appropriately by ensuring that the academic success criteria includes management traits and factors to facilitate business management approach to higher education sector.

\section{IHE (University/College) Council Implementation Level:}

IHE stakeholders hold the view that IHE managers must, of necessity hold chief executive officers' qualifications and requirement to lead and manage IHE rather than the current scenario where technically skilled fellows are appointed Vice Chancellors, often with management gaps glaring. Thus the MoHTEISTD should dissuade itself from appointing Professors as Vice Chancellors but appoint CEOs. 5.0 must be a template across stakeholders as there is a danger of leaving important stakeholders behind till too late

\section{REFERENCES}

1) Aluko, R.O., Adenuga, O.A., Kukoyi, P.O., Soyingbe, A.A. and Oyedeji, O.O. 2016. Predicting the Academic Performance of Architecture Students by Pre-enrolment Requirement: Using Machine-Learning Techniques, Construction Economics and Building, 16(4), 86-98, DOI: $\underline{\text { http://dx.doi.org/10.5130/AJCEB.v16i4.5184 }}$

2) Aysan, F., Tanrı̈ğğen, G., \& Tanrı̈ğen, A., 1996. Perceived Causes of Academic Failure among the Students at the Faculty of Education at Buca. U.S. Department of Education, (ERIC Document Reproduction Service No. ED406326)

3) Biggs, J. and Tang, C., 2011. Teaching for Quality Learning at University, $4^{\text {th }}$ ed. Berkshire: a. McGraw-Hill

4) Bomia, L., Beluzo, L., Demeester, D., Elander, K., Johnson, M. \& Sheldon, B., 1997. The Impact of Teaching Strategies on Intrinsic Motivation, Champaign, IL: ERIC Clearinghouse on Elementary and Early Childhood Education. Bone, E.K. and Reid, R.J., 2011. Prior Learning in Biology at High School Does Not Predict

5) Performance in the First Year at University, Higher Education Research and Development, 30(6), p.709-724, doi: https://doi.org/10.1080/07294360.2010.539599

6) Bovill, C. and Bulley, C.J., 2011. A Model of Active Student Participation in Curriculum

a. Design: Exploring Desirability and Possibility.

7) Brookshire, R.G., Crews, T.B., \& Brown, H.F., III., 2009. Student Success in a University Introductory Networks and Telecommunications Course: Contributing factors. International Journal of Information and Communication Technology Education, 5(1), 53-61

8) Bryson, C., 2014a. Clarifying the Concept of Student Engagement. In: Bryson, C. (ed.) a. Understanding and Developing Student Engagement. Abingdon: Routledge, 1-22

9) Bryson, C., 2014b. Reflections, and Considerations about the Future of Student Engagement. In: Bryson, C. (ed.) Understanding and developing student engagement. Abingdon: Routledge, 231-240

10) Busato, V.V., Prins, F.J., Elshout, J.J., \& Hamaker, C., 2000. Intellectual Ability, Learning Style, Personality, Achievement Motivation and Academic Success of Psychology Students in Higher Education, Personality and Individual Differences, 29(6), 1057-1068. doi:10.1016/s0191-8869(99)00253-6

11) Cachia, M., Lynam, S. \& Stock, R., 2018. Academic Success: Is it just about the grades? Higher Education Pedagogies, 3:1, 434-439 https://doi.org/10.1080/23752696.2018.1462096

12) Chou, D.C., 2012. Building a Successful Partnership in Higher Education Institutions, DOI:10.1504/IJISCM.2012.050350Corpus ID: 33625468, Int. J. Information Systems and Change Management, Vol. 6, No. 1, 2012 (IJISCM)

13) Cook-Sather, A. and Felten, P., 2017. Ethics of Academic Leadership: Guiding Learning and Teaching, Cosmopolitan perspectives on academic leadership in higher education, pp.175-191 
Reconfiguring the Academic Success Matrix through Student Involvement: Implications for a Higher Education Institutions: A Case of Three Selected Universities in Zimbabwe

14) Cook-Sather, A., Bovill, C., Felten, P., 2014. Engaging Students as Partners in Learning and a Teaching: a Guide for Faculty, San Francisco: Jossey-Bass

15) Creswell, J., $\quad$ Plano Clark, V.L., 2011. Designing and Conducting Mixed Methods Research, $\quad 2^{\text {nd }} \quad$ ed. $\quad$ Thousand Oaks, CA: Sage

16) Curran, R., 2017. A Framework for Student Staff Partnership in Higher Education (Doctoral

a. dissertation, University of Westminster)

17) Denzin, N.K., 1978. Triangulation. In: Denzin, N.K. (Ed.), The Research Act: An

a. Introduction to Sociological Methods. New York: McGraw-Hill

18) Eddy, P.L., 2010. "Partnerships and Collaborations in Higher Education" (2010). School of Education Book, Chapters 38, https://scholarworks.wm.edu/educationbookchapters/38

19) Entwistle, N., 2009. Teaching for Understanding at University: Deep Approaches and

a. Distinctive Ways of Thinking. Basingstoke: Palgrave Macmillan

20) Evans, C., Muijs, D., \& Tomlinson, M., 2015. Engaged Student Learning: High-impact

a. Strategies to Enhance Student Achievement. York: HE Academy

21) Garwe, E. and Thondhlana, J., 2019. Higher Education Systems and Institutions, Zimbabwe. Encyclopedia of international higher education systems and institutions. Dordrecht: Springer

22) Gunuc, S., 2014. The Relationships between Student Engagement and their Academic Achievement, International Journal on New Trends in Education and Their Implications, 2014 Volume: 5 Issue: 4 Article: 19 ISSN 1309-6249www.ijonte.org

23) Hardy, C. and Bryson, C., 2016. The Salience of Social Relationships and Networks in Enabling Student Engagement and Success. Student Engagement in Higher Education Journal, 1(1)

24) Harper, S.R. \& Quaye, S.J. (ed.), 2009. Student Engagement in Higher Education. New York

a. and London: Routledge

25) Haughery, J.R., 2017. "Student Motivation and Academic Success: Examining the Influences, Differences, and Economics of Mechatronic Experiences in Fundamental Undergraduate Courses", Graduate Theses and Dissertations. 16142. https://lib.dr.iastate.edu/etd/16142

26) Healey, M., Flint, A., Harrington, K. (2016). Students as partners: Reflections on a Conceptual Model, Teaching \& Learning Inquiry, 4(2)

http://dx.doi.org/10.20343/teach learninqu.4.2.3

27) Healey, M., Flint, A. \& Harrington, K., 2014. Engagement through Partnership: Students as

a. Partners in Learning and Teaching in Higher Education, York: HE Academy

28) Herminio, R.P., 2005. Factors Influencing Students' Academic Performance in the First Accounting Course: A Comparative Study between Public and Private, $\mathrm{PhD}$ thesis, Florida: Universities in Puerto Rico

29) Hu, S. \& Kuh, G.D., 2001. Being (Dis) Engaged in Educationally Purposeful Activities: The Influences of Student and Institutional Characteristics. Paper presented at the American Educational Research Association Annual Conference, Seattle, WA, 10-14 April

30) Jeffrey, L. (ed.), 2011. Academic Success Factors: An IT Student Perspective, Journal of

a. Information Technology Education Volume 10, 2011

31) Johnson, R.B., Onwuegbuzie, A.J., Turner, L.A., 2007. Toward a Definition of Mixed Methods Research, Journal of Mixed Methods Research 1, 112-133

32) Kamphorst, J.C., Adriaan Hofman, W.H., Jansen, E.P., \& Terlouw, C., 2015. Explaining Academic Success in Engineering Degree Programs: Do Female and Male Students Differ? Journal of Engineering Education, 104(2), 189-211

33) Kinzie, J. and Kuh, G., 2016. Review of Student Success Frameworks to Mobilize Higher Education, Indiana University Center for Postsecondary Research, Lumina Foundation Krause, K. and Coates, H., 2008. Students' Engagement in FirstYear University, Assessment

a. and Evaluation in Higher Education, 33(5), 493-505

34) Kuh, G.D., 2009. What Student Affairs Professionals Need to Know About Student Engagement, Journal of College Student Development, 50(6), 683-706

http://cpr.iub.edu/uploads/Assessing_What_Really_Matters_To_Student_Learning \%28Kuh,\%202001\%29.pdf

35) Kumari, G., 2016. Teacher-parent collaboration in two primary schools' special education integrated programmes: Application of Epstein's framework (Doctoral dissertation).

http://studentsrepo.um.edu.my/6255/1/GIRIJA_KUMARI_AP_K.S.NAYOR.pdf

36) Levy, P., Little, S. and Whelan, N., 2011. Perspectives on Staff-Student Partnerships in Learning, Research and Educational Enhancement. In: Little, S. (ed.) Staff-student partnerships in higher education. London: Continuum, 1-15 
Reconfiguring the Academic Success Matrix through Student Involvement: Implications for a Higher Education Institutions: A Case of Three Selected Universities in Zimbabwe

37) Liehr, S., Röhrig, J., Mehring, M. and Kluge, T., 2017. Article- How the Social-Ecological

38) Systems Concept Can Guide Transdisciplinary Research and Implementation: Addressing Water Challenges in Central Northern Namibia Light, R.J., 1992. The Harvard Assessment Seminars: Second Report, Harvard University Light, R.J., 2004. Making the Most of College, Harvard University Press. Retrieved from

https://books.google.com/books?hl=en\&lr=\&id=3fIXBAAAQBAJ\&oi=fnd\&pg=PP8\&dq=Making+the+Most+of+College\&o $\underline{\text { ts }=\text { CYThhEM8q Y\&sig=P11Owj_p8G1f4Ln6xerQySrGrac }}$

39) Ling, Y.Y., Khai Ng, P., and Leung, M.Y., 2010. Predicting the Academic Performance of Construction Engineering Students by Teaching and Learning Approaches: Case study, Journal of Professional Issues in Engineering Education and Practice, 137(4), p.277-284.

doi: https://doi.org/10.1061/(ASCE)EI.1943-5541.0000060

40) Lynam, S., \& Cachia, M., 2017. Students' Perceptions of the Role of Assessments at Higher Education, Assessment and Evaluation in Higher Education, 43(2), 223-234.

doi:10.1080/02602938.2017.1329928

41) Matthews, K.E., 2016. Students as Partners as the Future of Student Engagement. Student Engagement in Higher Education Journal, 1 (1), https://journals.gre.ac.uk/index.php/raise/issue/view/46/showToc (Accessed 7

a. September 2016)

42) Mayer, M.J. \& Patriarca, L.A., 2007. Behavioral Scripts and Instructional Procedures for

43) Students with Learning and Behavioral Problems, Preventing School Failure, 52(1), 3-12

44) McKenzie, K., \& Schweitzer, R., 2001. Who Succeeds at University? Factors Predicting

45) Academic Performance in first year Australian University Students, Higher Education Research and Development, 20(1), 21-33

46) Mercer-Mapstone, L., Dvorakova, S.L., Matthews, K.E., Abbot, S., Cheng, B., Felten, P., Knorr, K., Marquis, E., Shammas, R. and Swaim, K., 2017. A Systematic Literature Review of Students as Partners in Higher Education, International Journal for Students as Partners, 1(1)

47) Mihaela, P.L., 2015. Psychological Factors of Academic Success. Procedia - Social and

a. Behavioral Sciences, 180, 1632-1637. doi:10.1016/j.sbspro.2015.02.318

48) Ncube, M., 2019. Exploring the Prevalence of the Sexually Transmitted Marks Phenomenon

a. in Higher Education Institutions. South African Journal of Science, 115(11/12)

49) Nelson, K.G., Shell, D.F., Husman, J., Fishman, E.J., \& Soh, L.-K., 2015. Motivational and Self-Regulated Learning Profiles of Students Taking a Foundational Engineering Course, Journal of Engineering Education, 104(1), 74-100

50) Phoenix, C., Osborne, N., Redshaw, C., Moran, R., Stahl-Timmins, W., Depledge, M., Fleming, L.E. \& Wheeler, B.W., 2013. Paradigmatic Approaches to Studying Environment and Human Health. Environmental Science and Policy, 25, 218228

51) Pintrich, P.R., Smith, D.A.F., Garcia, T., \& Mckeachie, W.J., 1993. Reliability and Predictive Validity of the Motivated Strategies for Learning Questionnaire (Mslq). Educational and Psychological Measurement, 53(3), 801-813, https://doi.org/10.1177/0013164493053003024

52) Ross, J., Drysdale, M., \& Schulz, R., 2001. Cognitive Learning Styles and Academic Performance in two post-secondary computer application courses, Journal of Research on Computing in Education, 33(4), 400-412

53) Wilson, D., Jones, D., Kim, M.J., Allendoerfer, C., Bates, R., Crawford, J., ... Veilleux, N., 2014. The Link between Cocurricular Activities and Academic Engagement in Engineering Education, Journal of Engineering Education, 103(4), 625-651

54) Win, R. and Miller, P.W., 2005. The Effects of Individual and School Factors on University Students' Academic Performance, Australian Economic Review, 38(1),p.1-18.

doi: https://doi.org/10.1111/j.1467-8462.2005.00349.x

55) York, T.T., Gibson, C. and Rankin, S., 2015. Defining and Measuring Academic Success, Practical Assessment, Research and Evaluation, 20(5), p.1-20. Available at:

http://pareonline.net/getvn.asp?v=20andn=5

56) von Stumm, S., Hell, B., \& Chamorro-Premuzic, T., 2011. The Hungry Mind: Intellectual Curiosity is the Third Pillar of Academic Performance. Perspectives on Psychological Science, 6(6), 574-588. 